\title{
Drinking water intake of newborn dairy calves and its effects on feed intake, growth performance, health status, and nutrient digestibility
}

\author{
H. K. J. P. Wickramasinghe, A. J. Kramer, and J. A. D. R. N. Appuhamy* \\ Department of Animal Science, lowa State University, Ames 50011
}

\section{ABSTRACT}

Although it is recommended to offer free drinking water (called drinking water hereafter) immediately after birth, producers wait, on average, $17 \mathrm{~d}$ to first offer drinking water to newborn dairy calves. The objective of this study was to examine water and feed intake, growth performance, health status, and nutrient digestibility of Holstein heifer calves offered drinking water from birth (W0) as compared with those offered it at $17 \mathrm{~d}$ of age (W17), when fed an ad libitum volume of milk. Thirty Holstein heifer calves, balanced for parity of the dam, birth weight, and birth week, were randomly assigned $(\mathrm{n}=15)$ to W0 or W17. Calves had free access to drinking water and a starter ration, offered in 2 separate buckets, until they were $70 \mathrm{~d}$ of age. Calves were bottle-fed with pasteurized whole milk $3 \times$ per day $(2.0 \mathrm{~kg} /$ feeding until d 14, and $3.2 \mathrm{~kg} /$ feeding thereafter). Calves were partially weaned (33\% of the milk allowance $1 \times$ per day) at $42 \mathrm{~d}$ of age and completely weaned at $49 \mathrm{~d}$ of age. Drinking water intake, starter intake, milk intake, ambient temperature, and the fecal consistency were recorded daily. Body weight, hip height, hip width, heart girth, and body length were measured weekly. Blood (drawn from a jugular vein) was analyzed for hematocrit and haptoglobin concentrations at $14 \mathrm{~d}$ of age. On d 69 and 70, total fecal output of individual calves was measured and analyzed for chemical composition to determine apparent total-tract digestibility of nutrients. When offered from birth, newborn calves consumed $0.75 \pm 0.05 \mathrm{~kg} / \mathrm{d}$ water aside from the water they received from ad libitum milk allowance during the first $16 \mathrm{~d}$. Once offered, W17 calves drank more water (59\%) than W0 calves during the preweaning period. Starter intake of W0 and W17 calves was similar, but W0 calves consumed $0.285 \mathrm{~kg} / \mathrm{d}$ more milk and tended to achieve greater body weight and heart girth compared with W17 calves during the

Received August 21, 2018.

Accepted September 18, 2018.

*Corresponding author: appuhamy@iastate.edu preweaning period. Offering water from birth versus offering it later did not affect the number of days with diarrhea, intensity of diarrhea, or blood hematocrit and haptoglobin concentrations of preweaned calves. Despite a similar starter intake, W0 calves had greater hip height, body length, apparent total-tract digestibility of acid detergent fiber and neutral detergent fiber, and feed efficiency than W17 calves postweaning (50 to 70 d of age). When followed up to 5 mo of age, W0 calves had greater body weight than W17 calves. Provision of drinking water immediately after birth could improve growth and development of calves pre- and postweaning, potentially by stimulating rumen development, thus increasing nutrient availability.

Key words: ambient temperature, drinking water, feed efficiency, hip height

\section{INTRODUCTION}

Water is an essential nutrient and is second in importance, behind oxygen, to sustain life and performance of a living organism (Beede, 2005). Failure to fulfill the water requirement of animals results in short- and long-term impairments of body functions, which are in turn reflected by lowered performance (Gottardo et al., 2002). Nonetheless, water requirements of livestock are often overlooked compared with the requirements of other nutrients. In dairy cattle, the situation is further aggravated for calves compared with mature cows (Beede, 2005; Kertz et al., 2017). Water contributes to about $80 \%$ of the BW of newborn Holstein heifer calves. The body water content dramatically decreases as calves grow and deposit more fat, displacing body water (Reid et al., 1955). Body water content however remains above $70 \%$ until about $40 \mathrm{~d}$ of age, which is still 10 percentage units greater than that of mature animals (Sekine and Hirose, 1968). Moreover, neonatal calves lose a great volume of water due to diarrhea, which is seemingly inevitable in many dairy operations. Body water losses further increase during warm weather. Even though water is a vital nutrient for calves, the requirement has been poorly described in current nutrient requirement models (e.g., NRC, 2001). 
Similar to other mammals, calves meet their water requirement via 3 methods: (1) free drinking water (hereafter called drinking water), (2) moisture from feed, and (3) metabolic water. Relative contribution of these sources to total water intake varies significantly between calves and mature cows. For instance, drinking water contributes to $82 \%$ (Appuhamy et al., 2014) of the total water input for lactating cows, whereas its contribution is less than $20 \%$ for calves as they receive the majority of their water via milk or milk replacer (Thomas et al., 2007). Therefore, the drinking water requirement of calves appears to be insignificant when separated from liquid feed intake. The USDA's National Animal Health Monitoring System study in 2014 (USDA, 2016) demonstrated that dairy producers wait for, on average, $17 \mathrm{~d}$ to first offer drinking water to newborn calves. Producers also seem to be hesitant to offer water to newborn calves, assuming it would cause diarrhea (Beede, 2005; Kertz et al., 2017). Overall, a lack of scientific evidence on drinking water intake (FWI) of newborn calves and its effect on their performance likely encumbers the effectiveness of efforts promoting the notion of offering drinking water to newborn calves at birth.

Thickett et al. (1981) indicated the importance in examining the effect of the age at which calves are first offered drinking water. Then, Kertz et al. (1984) conducted an observational study using data from several calf trials conducted by Ralston Purina (St. Louis, MO) and demonstrated more than $30 \%$ increase in starter intake and weight gain in calves receiving drinking water from birth compared with calves deprived of drinking water until they were $28 \mathrm{~d}$ of age. Those astounding responses could be related to 2 aspects of the study: (1) calves did not receive much water from liquid feed as the daily milk replacer allowance was only $3.8 \mathrm{~kg} / \mathrm{d}$, and (2) calves were weaned as early as $28 \mathrm{~d}$ of age (after $3 \mathrm{~d}$ of transition milk), whereas the water requirement per unit of BW was quite high. Given the fact that the majority of modern dairy calves are fed more than 3.8 $\mathrm{kg} / \mathrm{d}$ of milk or milk replacer daily and weaned at a much later age (USDA, 2016), the relevance of the findings in Kertz et al. (1984) might need to be reevaluated for modern dairy production systems. Depending on the improved starter intake and weight gain in Kertz et al. (1984), it is often hypothesized that drinking water would enhance rumen development, thus increasing nutrient availability for growth and development of calves. However, no systematic attempt has been made to study this link between FWI and nutrient availability to the animal. Therefore, the objectives of this study were (1) to determine FWI of newborn calves, and (2) to investigate the effect of first offering drinking water from birth versus $17 \mathrm{~d}$ later on milk and starter intake, growth performance, health status, and nutrient digestibility in dairy heifer calves fed ad libitum amounts of liquid feed.

\section{MATERIALS AND METHODS}

All animal procedures in this study were conducted under approval of the Animal Care and Use Committee at Iowa State University. The experiment was conducted from August to December of 2017 at the Dairy Research and Teaching Unit at Iowa State University (ISU Dairy). Thirty Holstein heifer calves born at the ISU Dairy from August 22 to October 8 in 2017 were used. All calves were bottle-fed at least $3.78 \mathrm{~kg}$ of thawed colostrum within the first $4 \mathrm{~h}$ of life. Colostrum was collected from cows at the ISU Dairy, pooled, aliquoted, and frozen in plastic bags (Dairy Tech Inc., Greeley, CO). Immediately after feeding colostrum, calves were matched for the week they were born, parity of the dam (primiparous or multiparous), and birth weight (BW0) and randomly allocated to 2 treatments (15 calves per treatment): (1) provision of drinking water from birth (W0), and (2) provision of drinking water $17 \mathrm{~d}$ after birth (W17). All the calves were housed in individual pens bedded with straw (floor area $=1.2 \mathrm{~m} \times 1.8 \mathrm{~m}$ ) in the indoor calf facility at the ISU Dairy until they were 9 wk old. At wk 10 calves were housed individually in a separate set of cages bedded with rubber mattresses [3/4 inch $(1.905 \mathrm{~cm})$ thick] for a digestibility trial involving total fecal collection (described in details below). At the end of the wk 10, calves were moved to the heifer barn at the ISU Dairy, where they were housed and fed in groups.

Once offered, each individual calf had free access to an ad libitum amount of clean drinking water in a plastic bucket throughout the study. Each plastic bucket had a maximum capacity of $7.5 \mathrm{~L}$. Water buckets were filled with clean potable water and the weight (bucket + water) was recorded before offering to calves at 0700 h. The water volume was monitored at 1400 and 2200 $\mathrm{h}$ and maintained above $50 \%$ of total bucket volume throughout the day. The buckets and leftover water were weighed before fresh water was offered the following morning. Drinking water intake $(\mathrm{kg} / \mathrm{d})$ of individual calves was calculated using the difference of fresh water weight and leftover water weight. A separate set of water buckets with similar water volumes was used to measure the evaporative water losses, of which the FWI calculations were corrected for. The temperature inside the calf barn was recorded using temperature loggers (Lascar Electronics Inc., Erie, PA) placed along the span of the barn, leaving an equal distance between each logger. 
We followed the standard operation procedures of the ISU Dairy for feeding the calves. All calves were bottle-fed with $2.0 \mathrm{~kg}$ of pasteurized liquid milk at each of the 3 feeding times per day $(0600,1400$, and 2200 h) until they were $14 \mathrm{~d}$ old. From d 14 to 42 , the milk volume was increased to $3.2 \mathrm{~kg} /$ calf per feeding. Calves were partially weaned on d 42 and fed $3.2 \mathrm{~kg}$ of milk only once per day (2200 h) until they were completely weaned on d 49. Actual weights of milk offered and leftover $(\mathrm{kg})$ were recorded. All calves received milk from the same batch of pasteurized milk at each feeding. All calves had free access to a pelleted starter with whole corn grain $(89 \%$ DM, $18 \%$ CP, $3.5 \%$ crude fat, $10 \%$ crude fiber, $13 \%$ ADF; Vita Plus Corporation, Madison, WI) in plastic buckets until they were $10 \mathrm{wk}$ old and moved to group pens. Feed buckets were separated from water buckets using a metal plank to reduce contaminations from each other. All calves were fed with the same batch of starter throughout the $10 \mathrm{wk}$. After recording the leftover starter weight, the buckets were filled with a known amount of fresh starter and offered to the calves at the same time $(0700 \mathrm{~h})$ that drinking water was offered. Daily starter intake of individual calves was calculated using the difference of offered feed and leftover feed weights. An ad libitum starter intake was maintained by offering $10 \%$ more starter relative to intake from the previous day.

Fecal consistency of neonatal calves was scored on a scale of 1 to 4 ( $1=$ normal, $2=$ viscous feces, 3 $=$ runny feces, and $4=$ runny feces with splatters). Calves with a fecal score of 2 or greater were offered an electrolyte (5.5-7.0\% Sodium, 1.65\% Potassium; Land O'Lakes Inc., Arden Hills, MN) solution (2 kg/calf) before the morning feeding. Calves with a fecal score of 4 received an extra volume of the electrolyte solution before the afternoon milk feeding until the consistency became normal.

Birth weight of individual calves was recorded immediately after birth. Body weight, hip height (HH), body length (BL), heart girth (HG), and hip width (HW) of individual calves were then measured weekly. All parameters were measured by the same person to maintain consistency of measurements each week. Average daily gain within each week was calculated by dividing the difference of consecutive weekly BW by 7. Blood was collected 2 to $3 \mathrm{~h}(0900 \mathrm{~h})$ after morning feedings on the days in which body measurements were recorded. Blood was drawn from the jugular vein into vacutainer tubes containing EDTA and heparin (Dickinson and Company, Buena, NJ) using 18-gauge, 1-inch $(2.54 \mathrm{~cm})$ needles. Blood was centrifuged at 2,000 $\times$ $g$ at $4^{\circ} \mathrm{C}$ for $25 \mathrm{~min}$. Blood plasma was separated and stored in a $-20^{\circ} \mathrm{C}$ freezer until subsequent analyses.
On d 65, calves were moved to a separate set of individual cages each having a rubber mattress to collect total daily fecal output. Calves were allowed to be acclimated to new cages with new bedding until starting fecal collection. Fecal collection began immediately after feeding at $0600 \mathrm{~h}$ on d 69 and lasted $48 \mathrm{~h}$. Feces from individual calves was scraped from the rubber mattress into a plastic scoop using a large baking spatula immediately after defecation. Feces in the scoop were then transferred to a plastic bag assigned to each calf. Fresh fecal weight from each bag was recorded every $4 \mathrm{~h}$ and eventually summed to obtain total feces output $(\mathrm{kg} / \mathrm{d})$. A sample of feces $(\sim 200 \mathrm{~g})$ collected within each $4-\mathrm{h}$ interval was retrieved and placed into a $-20^{\circ} \mathrm{C}$ freezer. Consequently, 6 samples representing feces were collected from each calf over a period of $24 \mathrm{~h}$. Later, those 6 samples were thawed completely and thoroughly mixed to obtain a composite sample of feces of each calf from each day of total fecal collection. Calves were fed with the same starter during the total fecal collection period. Composite samples of the starter offered and leftover from each calf were obtained and stored at $-20^{\circ} \mathrm{C}$ until analysis. Once fecal collection was completed at the end of $d 70$ (the end of the experiment), calves were moved to heifer barn and followed until 5 mo of age, at which BW were measured to see any long-term effects of the treatments. One calf from the W0 treatment that was diagnosed with aspiration pneumonia and died at wk 7 of age was not replaced and the data were excluded.

Blood samples collected at the end of wk 2 were analyzed for plasma concentrations of haptoglobin (HPT) using a commercially available ELISA kit according to the manufacturer's instructions (Immunology Consultants Laboratory Inc., Portland, OR). Blood samples were also analyzed for hematocrit (Hct), Na, K, and $\mathrm{pH}$ using a portable blood analyzer system (Abbott Laboratories, East Windsor, NJ). Approximately 200 $\mathrm{g}$ of sample from feces, starter offered, and starter leftover was dried in an oven at $60^{\circ} \mathrm{C}$ for $72 \mathrm{~h}$ to determine DM. The dried samples were analyzed (Cumberland Valley Analytical Services, Waynesboro, PA) for CP $(\mathrm{N} \times 6.25 ;$ AOAC International, 2000; method 990.03), NDF (Van Soest et al., 1991), ADF (AOAC International, 2000; method 973.18), starch (Hall, 2009; with correction for free glucose), and ether extract (AOAC International, 2000; method 920.39).

Treatment effects on FWI, milk and starter intake, growth performance (BW, BL, HW, $\mathrm{HG}$, and $\mathrm{HH}$ ), ADG, and fecal scores, for which each calf has multiple measurements at different time points, were determined using the MIXED procedure with REPEATED option of SAS (version 9.4, SAS Institute Inc., NC) according to the following model: 


$$
\mathrm{Y}_{\mathrm{ijk} l}=\mu+\mathrm{T}_{\mathrm{i}}+\mathrm{P}_{\mathrm{j}}+\mathrm{W}_{\mathrm{k}}+\mathrm{C}_{\mathrm{l}}+\mathrm{TMP}_{\mathrm{ijkl}}+\mathrm{e}_{\mathrm{ijkl}},
$$

where $Y_{\mathrm{ijkl}}=$ the response variable of interest, $\mu=$ the overall mean, $\mathrm{T}_{\mathrm{i}}=$ the fixed effect of the ith treatment $(\mathrm{i}=\mathrm{W} 0$ and $\mathrm{W} 17), \mathrm{P}_{\mathrm{j}}=$ the fixed effect of the jth parity of the dam ( $\mathrm{j}=$ primiparous and multiparous $), \mathrm{W}_{\mathrm{k}}=$ the fixed effect of the kth week of age, $\mathrm{C}_{1}=$ the random effect of the lth calf, $\mathrm{TMP}_{\mathrm{ijkl}}=$ the fixed covariate effect of daily mean ambient temperature, and $\mathrm{e}_{\mathrm{ijkl}}=$ the random error assumed to be independent and identically distributed from a normal distribution with a mean of 0 and a variance of $\sigma^{2}\left[\sim N\left(\mathbf{0}, \mathbf{I} \sigma^{2}\right)\right]$. The treatment effects on nutrient digestibility measured on d 69 and 70 were tested with the above model excluding the week effect. Interactions among treatments, parity, and week were initially tested but were not included in the model as they were not statistically significant. The treatment effects on plasma HPT, blood Hct, blood electrolytes, and $\mathrm{pH}$ were tested excluding the week effect and the random calf effect using the GLM procedure of SAS as individual calves provided only a single measurement at wk 2. Pair-wise comparisons of treatments means were carried out with the Tukey-Kramer adjustment test. Statistical differences were declared at $P<0.05$ and a tendency toward significance was considered at $0.05<P<0.10$.

\section{RESULTS AND DISCUSSION}

The main objective of this study was to examine the importance of providing drinking water to newborn dairy calves from birth in terms of water and nutrient intake, nutrient digestibility, growth performance, and health. Offering drinking water from birth was evaluated in comparison to a $17 \mathrm{~d}$ delay as dairy producers in the United States wait, on average, $17 \mathrm{~d}$ to first offer drinking water to newborn dairy calves (USDA, 2016). This delay has existed for several years as the National Animal Health Monitoring System study in 2007 also indicated that dairy producers waited, on average, $15 \mathrm{~d}$ to first offer drinking water to newborn dairy calves (USDA, 2007). The majority of producers seem to assume that neonatal calves receive adequate amounts of water from milk or milk replacer to fulfill the total water requirement of the body. Given the water requirement of calves is poorly described in our current nutrient requirement models (e.g., NRC, 2001) and few published research articles involve water intake measurements of calves (Kertz et al., 2017), it is difficult to systematically evaluate the rationality of this consideration. In the present study, we measured FWI of calves daily fed a high volume of milk (6.0 to 9.6 $\mathrm{kg} / \mathrm{d}$ ) representing approximately the 70th percentile of liquid feed allowance across US dairy operations
(USDA, 2016). Therefore, a significant FWI observed, independent of water in liquid feed intake (milk, in the present study), should be applicable to the majority of dairy operations.

\section{Water Intake}

Treatment effects on FWI, and total water intake measurements are given in Table 1. Mean FWI in each week of the experiment are shown in Figure 1. Calves from the W0 treatment consumed, on average, $0.75 \pm$ $0.05 \mathrm{~kg} / \mathrm{d}$ of water aside from the water consumed via milk during the first $16 \mathrm{~d}(P<0.01)$. They had a mean milk intake of $6.25 \mathrm{~kg} / \mathrm{d}$ during this period. Assuming water comprises $87 \%$ of milk (Winchester and Morris, 1956), the mean total water intake during this period was $6.19 \mathrm{~kg} / \mathrm{d}$. Given the fact that $45 \%$ of dairy calves are fed less than $5.0 \mathrm{~kg}$ of milk or milk replacer daily and producers wait, on average, $17 \mathrm{~d}$ to offer drinking water to newborn calves (USDA, 2016), a large number of dairy calves in the United States appear to consume less water than their requirement during the first $2 \mathrm{wk}$ of their life. Kertz et al. (1984) pioneered the importance of offering drinking water to dairy calves at birth. They found that calves offered water from birth had a higher FWI $(1.40 \mathrm{~kg} / \mathrm{d})$ compared with that of our calves during the first $2 \mathrm{wk}$. This discrepancy could be primarily due to a lower contribution of milk replacer $(11.4 \% \mathrm{DM})$ to total water intake as they fed a lower volume of milk replacer compared with that of milk fed during the first 2 wk $(3.8$ vs. $6.0 \mathrm{~kg} / \mathrm{d}$ in Table 1). Despite the progressive increase in BW (Figure 2), W0 calves had similar FWI $(0.82 \pm 0.04 \mathrm{~kg} / \mathrm{d})$, even during the remainder of the preweaning period (Table 1 and Figure 1). In line with the milk allowance increase (6.0 to $9.6 \mathrm{~kg} / \mathrm{d}$ ) at $2 \mathrm{wk}$ of age, W0 calves consumed nearly $2.0 \mathrm{~kg} / \mathrm{d}$ more milk between 16 and $42 \mathrm{~d}$ of age compared with the milk consumption during first $16 \mathrm{~d}$ $(8.20$ vs. $6.25 \mathrm{~kg} / \mathrm{d})$. Consequently, the total daily water intake increased by $1.77 \mathrm{~kg} / \mathrm{d}$ from the first $16 \mathrm{~d}$ to the remainder of the preweaning period (7.96 vs. 6.19 $\mathrm{kg} / \mathrm{d}$, Table 1 ). This increment seemed to be adequate enough to fulfill body water requirements of tissue accretion and maintenance of increasing BW (Figure 2). Sekine and Hirose (1968) demonstrated that total body water content of dairy calves decreased from 80 to $70 \%$ during the first $40 \mathrm{~d}$. Reid et al. (1955) reported an inverse relationship between body water and body fat content emphasizing the fact that animals deposit fat displacing body water. Overall, the potential increase in body water requirement of growing calves appears to be slower than the rate of body growth. Because we offered ad libitum amounts of drinking water and milk, the total water intake measurements in Table 1 can 
Table 1. Free drinking water intake (FWI), pasteurized whole milk intake, starter intake, and total water intake of Holstein heifer calves first receiving free drinking water from birth (W0) or $17 \mathrm{~d}$ later (W17)

\begin{tabular}{|c|c|c|c|c|}
\hline \multirow[b]{2}{*}{ Variable } & \multicolumn{2}{|c|}{ LSM } & \multirow[b]{2}{*}{ SEM } & \multirow[b]{2}{*}{$P$-value } \\
\hline & W0 & W17 & & \\
\hline \multicolumn{5}{|l|}{ FWI, $\mathrm{kg} / \mathrm{d}$} \\
\hline 0 to $16 \mathrm{~d}$ & 0.75 & 0.00 & 0.05 & $<0.001$ \\
\hline 17 to $42 \mathrm{~d}$ & 0.82 & 1.30 & 0.04 & $<0.001$ \\
\hline 43 to $49 \mathrm{~d}$ & 1.88 & 2.02 & 0.10 & 0.327 \\
\hline 50 to $70 \mathrm{~d}$ & 5.26 & 5.32 & 0.09 & 0.613 \\
\hline \multicolumn{5}{|c|}{ Milk intake, kg/d } \\
\hline 0 to $16 \mathrm{~d}$ & 6.25 & 5.89 & 0.10 & 0.012 \\
\hline 17 to $42 \mathrm{~d}$ & 8.20 & 7.96 & 0.07 & 0.035 \\
\hline 43 to $49 \mathrm{~d}$ & 2.85 & 2.75 & 0.08 & 0.344 \\
\hline 50 to $70 \mathrm{~d}$ & - & - & - & - \\
\hline \multicolumn{5}{|c|}{ Starter intake, $\mathrm{kg} / \mathrm{d}$} \\
\hline 0 to $16 \mathrm{~d}$ & 0.02 & 0.02 & 0.01 & 0.427 \\
\hline 17 to $42 \mathrm{~d}$ & 0.06 & 0.06 & 0.01 & 0.944 \\
\hline 43 to $49 \mathrm{~d}$ & 0.66 & 0.70 & 0.04 & 0.521 \\
\hline 50 to $70 \mathrm{~d}$ & 2.36 & 2.27 & 0.04 & 0.115 \\
\hline \multicolumn{5}{|c|}{ Total water intake, ${ }^{1} \mathrm{~kg} / \mathrm{d}$} \\
\hline 0 to $16 \mathrm{~d}$ & 6.19 & 5.16 & 0.11 & $<0.001$ \\
\hline 17 to $42 \mathrm{~d}$ & 7.96 & 8.23 & 0.07 & 0.012 \\
\hline 43 to $49 \mathrm{~d}$ & 4.42 & 4.48 & 0.10 & 0.701 \\
\hline 50 to $70 \mathrm{~d}$ & 5.48 & 5.59 & 0.09 & 0.384 \\
\hline
\end{tabular}

${ }^{1} \mathrm{FWI}+($ milk intake $\times 0.87)+($ starter intake $\times$ moisture content of starter $)$.

be considered as voluntary water intake measurements, potentially reflecting the actual total water requirement of the body. Unlike water in milk, which is shunted directly to the abomasum, drinking water enters and becomes a part of the developing reticulorumen (hereafter called rumen) of preweaned calves (Govil et al., 2017). Therefore, voluntary FWI of preweaned calves $(0.75$ to $0.82 \mathrm{~kg} / \mathrm{d}$, Table 1$)$ partially represents a water requirement of the developing rumen.

Once offered, W17 calves consumed, on average, about $0.48 \mathrm{~kg} / \mathrm{d}(59 \%)$ more water $(P<0.001)$ than W0 calves between d 17 and 42 (Table 1). This increment in drinking water was constant until calves were weaned partially (Figure 1). Therefore, the age at which drinking water is first offered to calves could be an important variable to consider in determining water intake of preweaned calves. Moreover, the excessive intake of drinking water might affect microbial fermentation in the rumen and thus rumen development. No study has examined the effect of water on rumen development of calves. Few studies focusing on the relationship between drinking water and rumen functions in mature cows provide some insight on potential effects of drinking water in calves. For instance, Rogers et al. (1982) and Fraley et al. (2015) found lower molar proportions of butyrate and propionate in the rumen, which were associated with lower liquid weight in the rumen and high fractional liquid passage rates in lactating cows with high FWI. Butyrate and propionate are often considered to be major drivers of morphological and metabolic developments of the rumen in calves
(Lane et al., 2000; Baldwin et al., 2004). Therefore, the increased FWI of W17 calves could be hypothesized to inversely affect rumen development.

Once calves were completely weaned, FWI of both groups increased from about 2.00 to $5.30 \mathrm{~kg} / \mathrm{d}$ (Table 1). In terms of total water intake (FWI plus water in milk and starter), however, calves consumed more water during the preweaning period compared with the postweaning period (e. g., 6.19 and 7.96 vs. 4.42 and $5.48 \mathrm{~kg} / \mathrm{d}$; Table 1). Calves require more water, partially due to increased water losses through diarrhea, which is seemingly inevitable during the preweaning period. Also, newborn calves can have an inherently greater water requirement than mature calves as their body water content is much higher than calves at 60 d of age (Sekine and Hirose, 1968). It is worth noting that we did not observe any behavior leading to spilling water from buckets during both pre- and postweaning periods in the present study.

Average daily ambient temperature had a significant effect on FWI. Because calves were born, and thus included in the study, at different time points (late August through early October), there are representative samples of calves at different ages exposed to various ambient temperatures. For instance, calves at 7 and 28 d of age were exposed to average daily ambient temperatures ranging from 7.6 to $26.5^{\circ} \mathrm{C}$, and from 5.6 to $24.4^{\circ} \mathrm{C}$, respectively. When adjusted for the treatment and age effects, FWI of pre- and postweaning calves increased by similar amounts $(0.068$ and $0.055 \mathrm{~kg}$, respectively) per unit $\left({ }^{\circ} \mathrm{C}\right)$ increase in average daily ambient 
temperature (Table 2). The increment during weaning, in which milk allowance was cut down by $67 \%$, was twice as much as that during the other periods (0.141 vs. 0.068 and $0.055 \mathrm{~kg}$ per $1.0^{\circ} \mathrm{C}$ ), emphasizing the importance of providing sufficient drinking water to calves being weaned under hot weather conditions.

\section{Milk and Starter Intake}

Mean milk intake and starter intake (kg/d) are given in Table 1. Regardless of the treatment, calves left, on average, $0.62 \pm 0.09 \mathrm{~kg} / \mathrm{d}$ and $1.27 \pm 0.09 \mathrm{~kg} / \mathrm{d}$ of milk in the bottles during the first $2 \mathrm{wk}$, and the rest of the preweaning period, respectively $(P<0.01$; data not shown), indicating that the milk allowances were ad libitum. The W0 calves consumed, on average, $360 \mathrm{~g} / \mathrm{d}$ (6.25 vs. $5.89 \mathrm{~kg} / \mathrm{d})$ and $240 \mathrm{~g} / \mathrm{d}(8.20$ vs. $7.96 \mathrm{~kg} / \mathrm{d})$ more milk than W17 calves during the first $16 \mathrm{~d}$ and
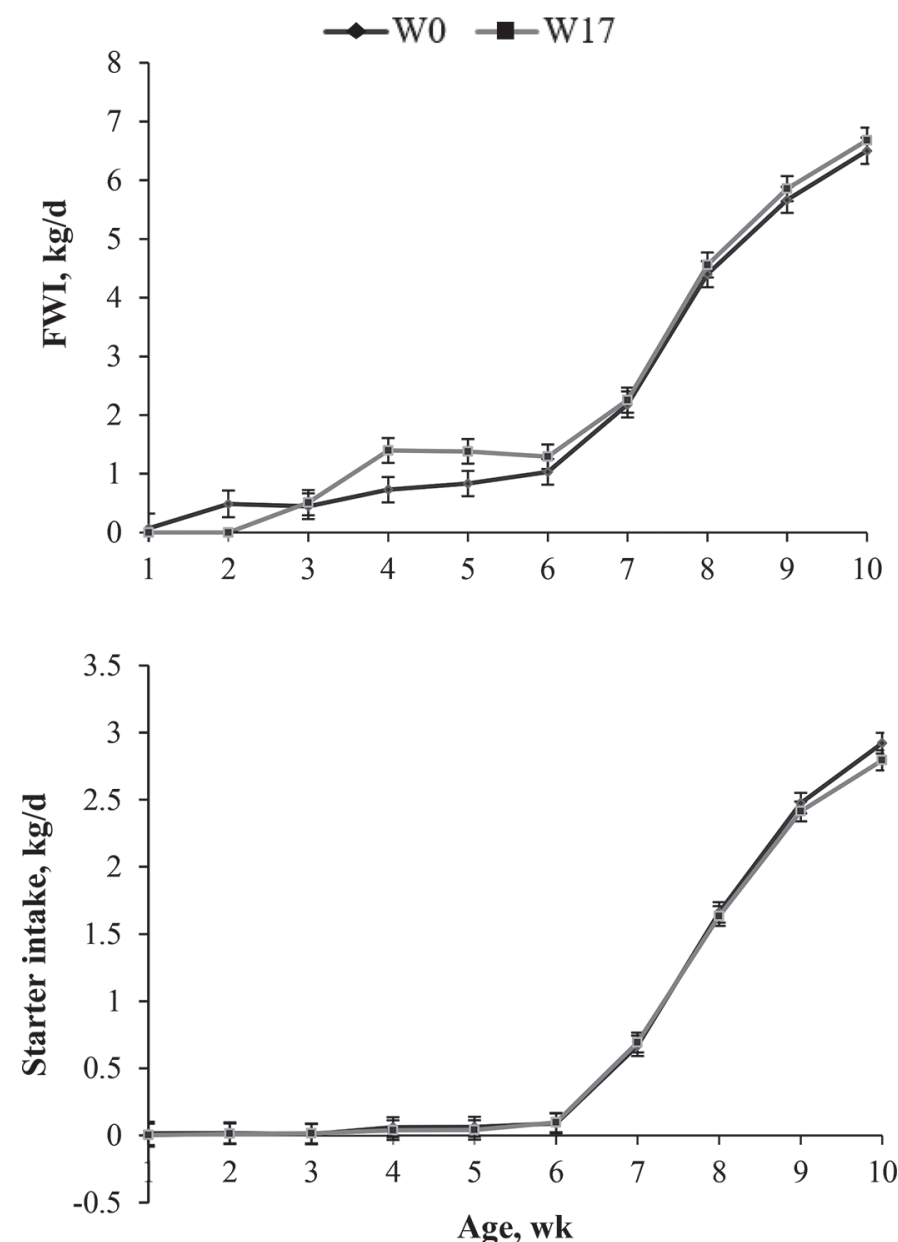

Figure 1. Weekly mean $( \pm$ SEM) drinking water intake $(\mathrm{FWI})$ and starter intake of Holstein heifer calves first receiving free drinking water from birth (W0) or $17 \mathrm{~d}$ later (W17) during the first $10 \mathrm{wk}$ of their life. All calves were partially weaned by reducing the milk allowance by two-thirds at $42 \mathrm{~d}$ of age and completely weaned at $49 \mathrm{~d}$ of age. thereafter, respectively (Table 1). Gottardo et al. (2002) also showed that provision of drinking water reduced milk refusals in veal calves. On the other hand, based on findings in Kertz et al. (1984), it is often considered that neonatal calves offered drinking water from birth consume more starter feed than those without access to drinking water. However, in the present study, we did not observe such an effect on starter intake (Table 1). Starter intake of our calves (0.02 to $0.06 \mathrm{~kg} / \mathrm{d}$ ) was much lower than the calves $(0.23$ to $0.95 \mathrm{~kg} / \mathrm{d}$ ) in Kertz et al. (1984) during the preweaning period. This could be due to a larger contribution of liquid feed (6.0 to 9.6 vs. $3.8 \mathrm{~kg} / \mathrm{d}$ ) to total DMI of calves in our study compared with that in Kertz et al. (1984). Through a meta-analysis, Gelsinger et al. (2016) demonstrated a significantly inverse relationship between milk or milk replacer intake and starter intake in preweaned calves. The drinking water restriction and its effects on starter intake in Kertz et al. (1984) also may have been more severe due to their water restriction being longer (28 vs. $16 \mathrm{~d})$ and the calves were weaned at a much earlier age $(<28$ d vs. 42 d) compared with our study. As observed with FWI, starter intake increased sharply once calves were partially weaned and exceeded $2.0 \mathrm{~kg} / \mathrm{d}$ a couple of weeks after they were completely weaned (Table 1). Starter intake was positively associated with FWI throughout the study (Figure 1). However, the relationship was much stronger during the postweaning period than the preweaning period $(\mathrm{r}=0.85$ vs. 0.14 ; Table 3$)$, suggesting that the commonly accepted strong positive relationship between drinking water intake and starter intake (Quigley et al., 2006) is reasonably applicable to calves fed lower milk or milk replacer allowances, which is the case in the majority of commercial dairy operations (USDA, 2016).

\section{Growth Performance}

Mean BW, BL, HG, HH, and HW during the preand postweaning periods are given in Table 4 . Figure 2 shows how they changed over the first $10 \mathrm{wk}$. Because BW0 was a main factor considered in the random assignment of calves to treatments, the mean BW0 of W0 and W17 were similar at $38.0 \mathrm{~kg}(P=0.785$, Table 4). Calves offered drinking water from birth tended to achieve greater $\mathrm{BW}$ during the preweaning period than W17 calves $(P=0.085$, Table 4$)$. The differences became more pronounced toward the end of the preweaning period (Figure 2). Average daily gain was not significantly different between W0 and W17 but W0 calves had numerically greater ADG than W17 calves during the preweaning period $(0.66 \pm 0.03$ vs. $0.61 \pm 0.03, P=0.227)$. Body weight was significantly correlated with HG ( $\mathrm{r}=0.95$; data not shown) across 


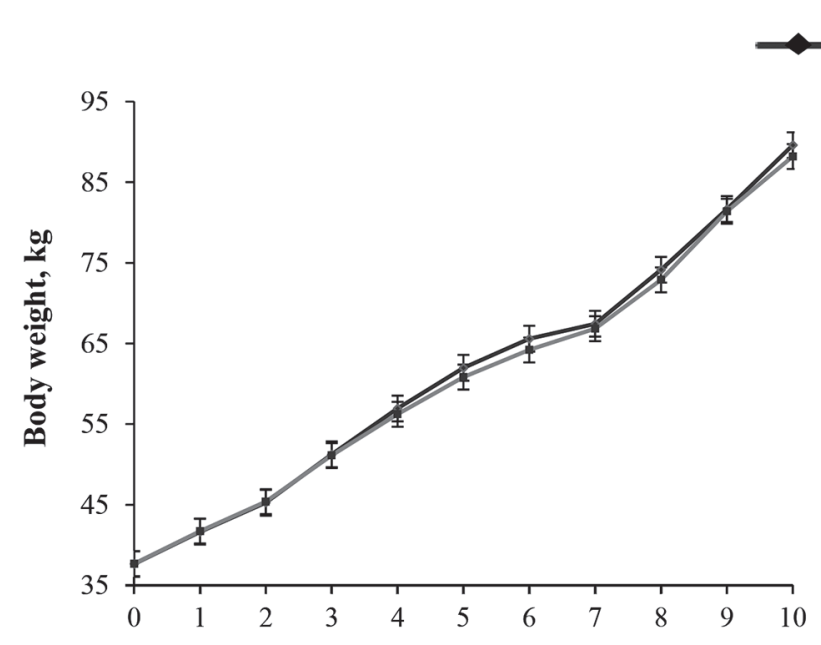

$-\mathrm{W} 0 \rightarrow-\mathrm{W} 17$
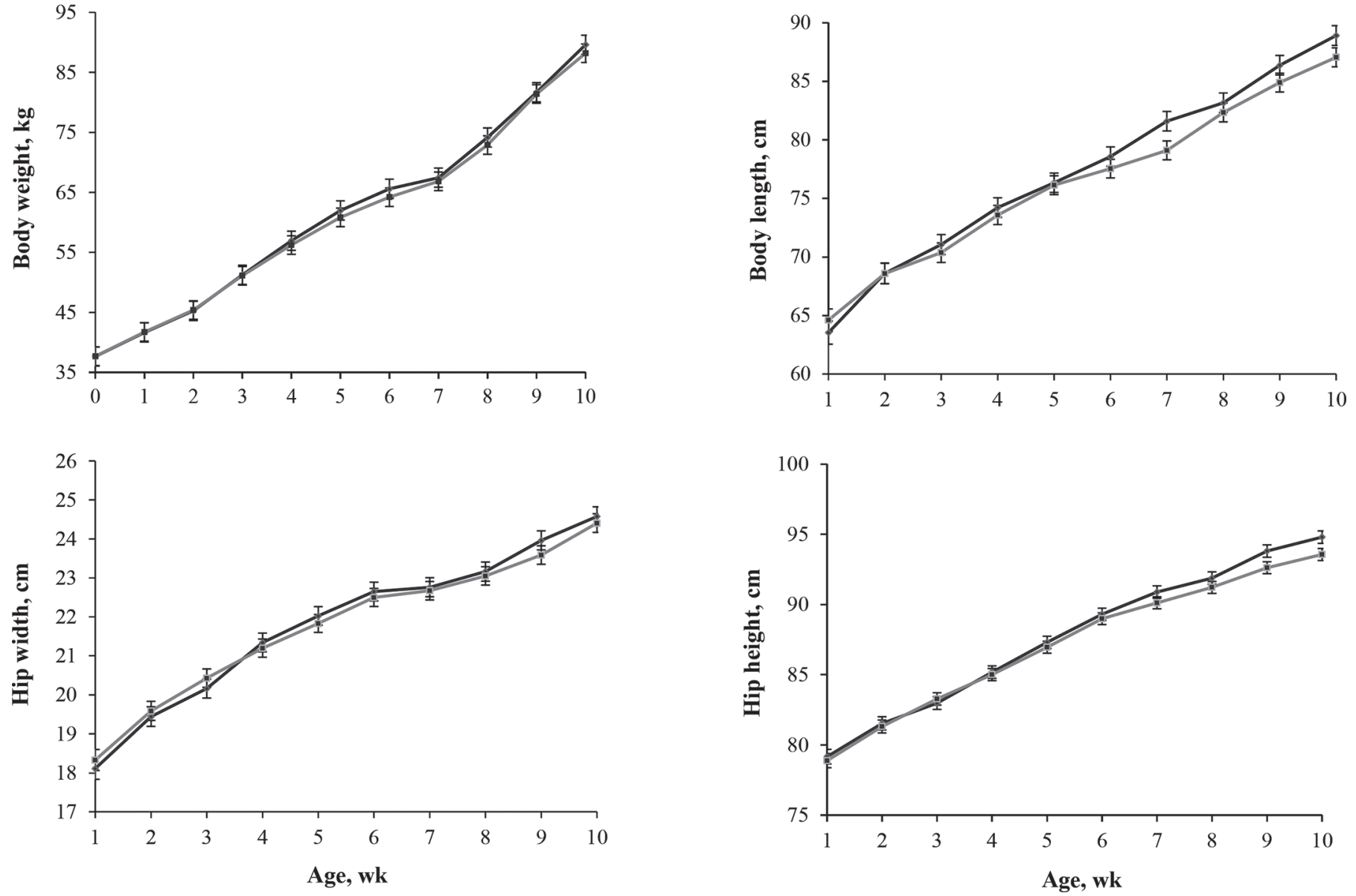

Figure 2. Weekly mean $( \pm \mathrm{SEM}) \mathrm{BW}$, body length, hip width, and hip height of Holstein heifer calves first receiving free drinking water from birth (W0) or $17 \mathrm{~d}$ later (W17) during the first $10 \mathrm{wk}$ of their life. All calves were partially weaned by reducing the milk allowance by two-thirds at $42 \mathrm{~d}$ of age and completely weaned at $49 \mathrm{~d}$ of age.

the treatments, indicating that HG is a sound proxy in determining BW of preweaned calves in commercial operations (Heinrichs et al., 2017). Consequently, W0

Table 2. Effects (regression coefficients) of mean daily ambient temperature on free drinking water intake (FWI), starter intake, and ADG of Holstein heifer calves

\begin{tabular}{lcr}
\hline Variable, $\mathrm{kg} / \mathrm{d}$ & Coefficient & $P$-value \\
\hline Preweaning $(0$ to $42 \mathrm{~d})$ & 0.068 & $<0.001$ \\
FWI & -0.0002 & 0.736 \\
Starter intake & 0.020 & $<0.001$ \\
ADG & 0.141 & $<0.001$ \\
During weaning (43 to $49 \mathrm{~d})$ & 0.002 & 0.816 \\
FWI & -0.019 & 0.352 \\
Starter intake & 0.055 & \\
ADG & -0.015 & 0.012 \\
Postweaning (50 to $70 \mathrm{~d})$ & -0.027 & 0.110 \\
FWI & & \\
Starter intake &
\end{tabular}

calves also tend to have greater HG $(P=0.091$; Table 4) than W17 calves. Age at which calves were first offered drinking water did not affect $\mathrm{BL}(P=0.656), \mathrm{HH}$ $(P=0.458)$, or HW $(P=0.794)$ of preweaned calves. Hip height and BL were positively correlated with BW $(\mathrm{r}=0.88$ and 0.81 , respectively; data not shown $)$, but the relationships were not as strong as that of HG $(\mathrm{r}=$

Table 3. Pearson correlation coefficients (r) and the corresponding $P$-values for relationships among drinking water intake (FWI), starter intake, and milk intake of Holstein heifer calves offered drinking water from birth and weaned at $42 \mathrm{~d}$ of age

\begin{tabular}{lcr}
\hline Relationship & $\mathrm{r}$ & $P$-value \\
\hline 0 to 42 d & & \\
FWI and starter intake & 0.14 & $<0.001$ \\
FWI and milk intake & 0.05 & 0.245 \\
Milk intake and starter intake & 0.04 & 0.298 \\
43 to 70 d & 0.85 & $<0.001$ \\
FWI and starter intake & & \\
\hline
\end{tabular}


0.95, data not shown) as shown previously by Wilson et al. (1997). Regardless of the treatments, ADG during the preweaning period had a significantly positive relationship $(P<0.001)$ with average daily ambient temperature (Table 2 ). Average daily gain increased by $20.0 \mathrm{~g}$ for each unit $\left({ }^{\circ} \mathrm{C}\right)$ increase in ambient temperature, but did not change starter intake. Daily mean ambient temperatures that preweaned calves experienced ranged from 6.1 to $24.8^{\circ} \mathrm{C}$, respectively. Thus, increasing ambient temperature within the thermoneutral zone appears to enhance tissue accretion in calves independent of DMI. Little information is available on the effects of ambient temperature on the growth of cattle. Kang et al. (2016) indicated that lipolysis that occurs during cold ambient temperatures (to generate heat) could result in decreased feed efficiency. Partial weaning with a restricted (to 33\%) milk allowance decreased ADG from about 0.60 to less than $0.40 \mathrm{~kg} / \mathrm{d}$ (Table 4). Calves exhibiting better growth performance during the preweaning period appear to be more negatively affected by the milk allowance restriction. Regardless of the treatments, ADG during weaning (d 43 to 49) was negatively associated with ADG during the week immediately before weaning $(\mathrm{r}=-0.39$ and $P=0.039$; data not shown). Low starter intake that primarily stem from high milk allowances (Gelsinger et al., 2016) during preweaning period likely caused calves to be illprepared for forthcoming weaning in the present study.

In line with the markedly increasing starter intake (Figure 1), BW increased significantly after calves were completely weaned (Figure 2). During the first $3 \mathrm{wk}$ postweaning, W0 and W17 calves had similar ADG and starter intake of 1.06 and $2.32 \mathrm{~kg} / \mathrm{d}$, respectively. Rosenberger et al. (2017) also observed similar ADG and starter intake postweaning for calves fed 8 to $10 \mathrm{~kg}$ of whole milk daily. Hip height and BL of W0 calves were greater than that of W17 during the postweaning period $(P<0.05$, Table 4$)$. Overall, calves having access to drinking water from birth had better structural growth compared with those first receiving drinking water at $d$ 17. Structural growth of calves has been shown to be positively related to future BW and milk yield during the first lactation (Van De Stroet et al., 2016). In the present study, W0 calves with greater $\mathrm{HH}$ and BL at 10 wk of age achieved greater BW at 5 mo of age (199.9 vs. $186.9 \mathrm{~kg}, P=0.048)$.

\section{Nutrient Digestibility Postweaning}

Nutrient intake, ATTD of nutrients, and FCE of calves at $10 \mathrm{wk}$ of age are given in Table 5. Intake of individual nutrients was similar between W0 and W17 calves, primarily due to similar starter intake during the final $2 \mathrm{~d}$ of the experiment (d 69 and 70) when total fecal output of individual animals was collected and sampled to determine ATTD of nutrients. The mean ATTD of DM, starch, CP, ether extract (fat), NDF, and ADF (Table 5) are consistent with the ranges previously reported (Terré et al., 2007; Hill et al., 2010; Castells et al., 2012; Montoro et al., 2013; Daneshvar et al., 2015; Chapman et al., 2016). The digestibility of starch and CP were not affected by the age at which calves were first offered drinking water $(P>0.550)$. Compared with W17 calves, W0 calves

Table 4. Growth performance of Holstein heifer calves first receiving free drinking water from birth (W0) or 17 d later $(\mathrm{W} 17)^{1}$

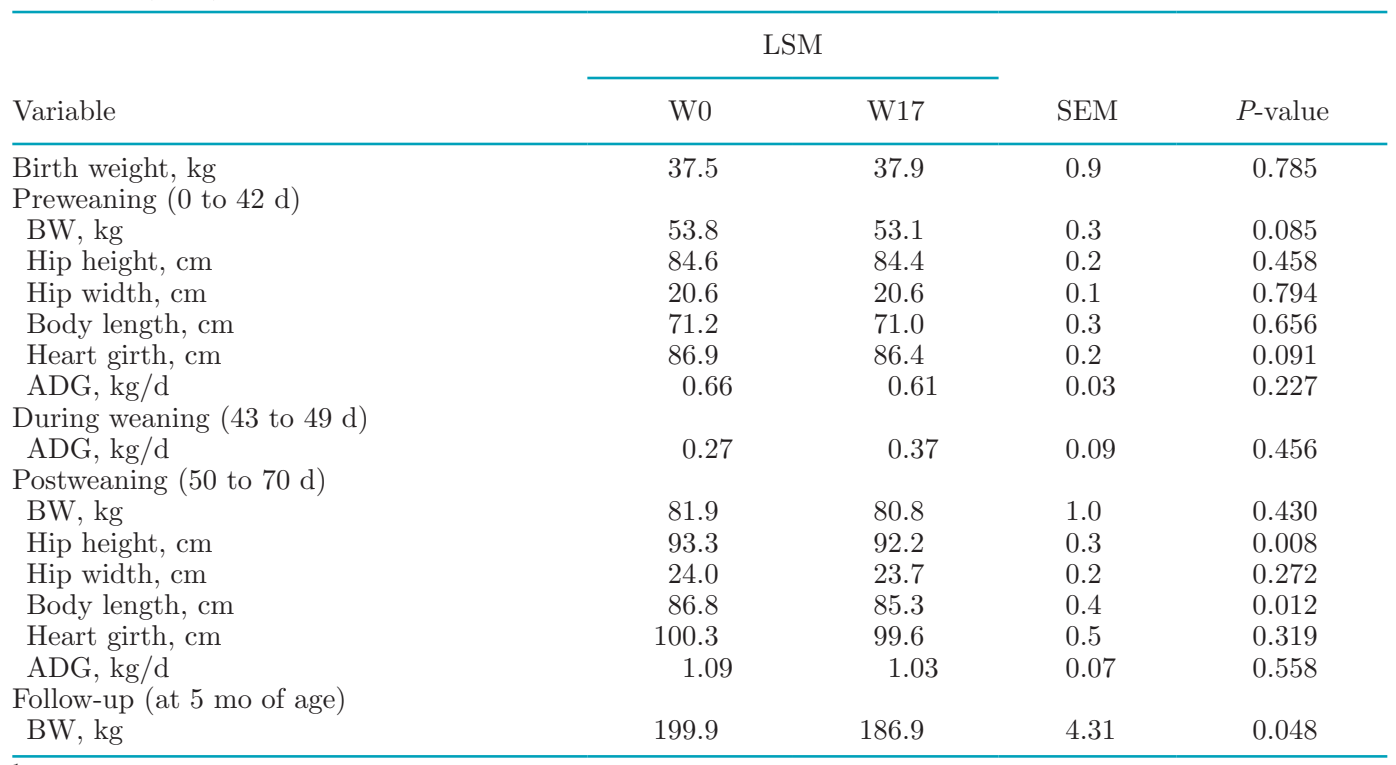

${ }^{1}$ Calves were partially and completely weaned at 42 and $49 \mathrm{~d}$, respectively. 
had greater ATTD of $\operatorname{ADF}(P=0.047)$ and tended to have greater ATTD of NDF $(P=0.078)$. Nonetheless, the discrepancies of ADF and NDF digestibility had no effect on DM digestibility (Table 5). Dennis et al. (2018) saw similar ATTD of DM postweaning despite the significantly changing ADF and NDF digestibility between calf groups fed different amounts DM from milk replacer. Opposed to the effects on ADF and NDF digestibility, calves offered drinking water from birth tended to have lower ATTD of fat $(P=0.094)$. Quigley et al. (2017) and Dennis et al. (2018) observed that ATTD of ADF and NDF were inversely related to ATTD of fat in weaned heifer calves fed different liquid feed allowances. The increased ADF and NDF digestibility were related to improved FCE postweaning $(P=0.057$, Table 5$)$, supporting the fact that increasing fiber digestibility greatly improves feed utilization efficiency of ruminants (Beauchemin et al., 2003).

Unlike milk, which is shunted directly to the abomasum via the esophageal groove, drinking water is capable of entering the rumen and becoming an integral part of its development (Govil et al., 2017). Drinking water can affect rumen development and establishment of its microbiome by altering the $\mathrm{pH}$, digesta mixing and passage, and VFA composition similar to what has been shown with the microbiome of mature cattle and humans (Rogers et al., 1982; Fraley et al., 2015; Sasada et al., 2015; Cremer et al., 2017). Given the fact that the contribution of the rumen to total-tract digestibility of fiber is substantially greater than the contribution from the other parts of the gut (Gressley et al., 2011), the improved NDF and ADF digestibility suggests an improved rumen function in calves offered drinking water from birth. Even though it has long been hypothesized that drinking water facilitates rumen development in calves, no systematic attempt has been made to explore those effects. Such an attempt will improve current understanding of development of the rumen and its microbiome and their relevance to growth and production performance of dairy heifers. Moreover, the new knowledge will assist in effectively educating producers on the importance of providing drinking water to dairy calves.

\section{Health Status}

Severity of diarrhea (scores of fecal consistency) and the number of days with diarrhea for W0 and W17 calves are given in Table 6. Some important blood parameters related to diarrhea are also shown in Table 6 . Age at which drinking water was offered did not have an effect on the severity of diarrhea $(P=0.209)$ or the number of days that calves had diarrhea $(P=0.890)$. Kertz et al. (1984) also reported an insignificant ef-
Table 5. Nutrient intake, apparent total-tract digestibility (ATTD, $\%$ ) of nutrients, and feed conversion efficiency (FCE) of Holstein heifer calves first receiving free drinking water from birth (W0) or $17 \mathrm{~d}$ later (W17) 3 wk after weaning (at $10 \mathrm{wk}$ of age)

\begin{tabular}{lcccc}
\hline \multirow{2}{*}{ Variable } & \multicolumn{2}{c}{ LSM } & & \\
\cline { 2 - 3 } & W0 & W17 & SEM & $P$-value \\
\hline Intake, kg/d & & & & \\
DM & 2.80 & 2.71 & 0.13 & 0.643 \\
CP & 0.60 & 0.58 & 0.03 & 0.642 \\
Starch & 0.95 & 0.91 & 0.05 & 0.529 \\
Ether extract & 0.12 & 0.12 & 0.01 & 0.535 \\
ADF & 0.57 & 0.57 & 0.03 & 0.949 \\
NDF & 0.76 & 0.75 & 0.04 & 0.854 \\
ATTD, \% & & & & \\
DM & 74.3 & 74.2 & 0.7 & 0.929 \\
CP & 73.4 & 73.3 & 1.5 & 0.982 \\
Starch & 97.6 & 98.1 & 0.5 & 0.564 \\
Ether extract & 86.3 & 89.0 & 1.0 & 0.094 \\
ADF & 55.1 & 50.2 & 1.6 & 0.047 \\
NDF & 51.2 & 47.2 & 1.5 & 0.078 \\
FCE & 0.49 & 0.34 & 0.05 & 0.057 \\
\hline
\end{tabular}

${ }^{1}$ ADG during wk 10/average DMI during wk 10.

fect of offering drinking water to newborn dairy calves on diarrhea. Disturbed electrolyte homeostasis in the blood, dehydration (as indicated by high blood Hct), and reduced blood $\mathrm{pH}$ (indicative of metabolic acidosis) are the most significant consequences of diarrhea in calves (Sayers et al., 2016). Blood HPT concentration has been identified as a useful tool in evaluating health status of dairy calves (Ganheim et al., 2007; Balikci and $\mathrm{Al}, 2014)$. Mean Hct, $\mathrm{pH}, \mathrm{Na}$ and $\mathrm{K}$ concentrations, and HPT concentration in blood at 2 wk of age, when the incidence of diarrhea was most prevalent (Table 6), were consistent with the values previously reported for neonatal calves (Reece, 1980; Bouda and Jagos, 1984; Ramin et al., 2012; Murray et al., 2014). Unaffected blood parameters, except $\mathrm{Na}$ concentration, further reinforce the observation that offering drinking water to newborn calves does not affect diarrhea or the general health status of calves. Blood Na concentration of W17 calves were greater than that of W0 calves (136.6 vs. $135.2 \mathrm{mmol} / \mathrm{L} ; P=0.035)$. However, none of those concentrations were representative of severe consequences associated with diarrhea. Trefz et al. (2017) saw that diarrhea significantly increased calf mortality when blood $\mathrm{Na}$ concentrations were greater than 151 $\mathrm{mmol} / \mathrm{L}$. It is worth reminding here that the calves in the present study were fed a relatively large amount of milk (6.0 to $9.6 \mathrm{~kg} / \mathrm{d}$ ), greatly contributing to their total water intake during the period (6 to $21 \mathrm{~d}$ of age) in which more than $90 \%$ of the diarrhea incidences occurred (data not shown). More prominent effects of water deprivation could be expected among calves having lower milk or milk replacer allowances (e.g., half of the dairy operations in the United States offering less than 
Table 6. Attributes of diarrhea and some blood parameters of Holstein heifer calves first receiving free drinking water from birth (W0) or 17 d later (W17)

\begin{tabular}{|c|c|c|c|c|}
\hline \multirow[b]{2}{*}{ Variable } & \multicolumn{2}{|c|}{ LSM } & \multirow[b]{2}{*}{ SEM } & \multirow[b]{2}{*}{$P$-value } \\
\hline & W0 & W17 & & \\
\hline \multicolumn{5}{|l|}{ Attributes of diarrhea ( 0 to $28 \mathrm{~d}$ ) } \\
\hline Days with diarrhea & 6.8 & 7.0 & 0.8 & 0.890 \\
\hline Fecal consistency score & 2.00 & 2.05 & 0.03 & 0.209 \\
\hline \multicolumn{5}{|l|}{ Blood parameter $(14 \mathrm{~d})$} \\
\hline Hematocrit, $\%$ of blood volume & 23.51 & 24.18 & 1.35 & 0.728 \\
\hline $\mathrm{Na}, \mathrm{mmol} / \mathrm{L}$ & 135.24 & 136.58 & 0.41 & 0.035 \\
\hline $\mathrm{K}, \mathrm{mmol} / \mathrm{L}$ & 4.33 & 4.25 & 0.10 & 0.571 \\
\hline $\mathrm{pH}$ & 7.43 & 7.41 & 0.01 & 0.359 \\
\hline Haptoglobin, $\mu \mathrm{g} / \mathrm{mL}$ & 65.88 & 128.26 & 51.12 & 0.406 \\
\hline
\end{tabular}

$5.0 \mathrm{~kg} /$ calf per d) and are raised under hot weather conditions associated with significant water losses from the body.

\section{CONCLUSIONS}

Holstein heifer calves drank $0.75 \mathrm{~kg}$ of drinking water daily aside from the water they receive from an ad libitum liquid feed allowance during the first 2 wk of life. Calves first receiving drinking water at about $2 \mathrm{wk}$ of age drank $59 \%$ more water than calves receiving it from birth during the rest of the preweaning period. Calves having access to free drinking water from birth drank about $300 \mathrm{~g}$ more milk and tended to achieve greater BW and HG preweaning and had greater apparent total-tract digestibility of NDF and ADF, feed efficiency, BW, HH, and BL postweaning. The age first offered free drinking water did not have an effect on starter intake, severity and duration of diarrhea, and general health status of calves. Regardless of the age first offered drinking water, calves fed a high volume of milk (6.0 to $9.6 \mathrm{~kg} / \mathrm{d}$ ) had low starter intake during preweaning period and experienced a significant decline in ADG during weaning. When offered from birth, neonatal dairy calves drank a significant amount of free water, which could potentially improve growth performance, both pre- and postweaning, possibly through a positive effect on rumen development and thus on nutrient utilization efficiency.

\section{ACKNOWLEDGMENTS}

The assistance received from Melissa Kosht and staff at the Calf Unit of Dairy Research and Teaching Unit at Iowa State University is gratefully acknowledged.

\section{REFERENCES}

AOAC International. 2000. Official Methods of Analysis. 17th ed. Association of Official Analytical Chemists, Arlington, VA.
Appuhamy, J. A. D. R. N., C. Wagner-Riddle, D. P. Casper, J. France, and E. Kebreab. 2014. Quantifying body water kinetics and fecal and urinary water output from lactating Holstein dairy cows. J. Dairy Sci. 97:6177-6195. https://doi.org/10.3168/jds.2013-7755.

Baldwin, R. L. VI, K. R. McLeod, J. L. Klotz, and R. N. Heitmann. 2004. Rumen development, intestinal growth and hepatic metabolism in the pre- and post-weaning ruminant. J. Dairy Sci. 87(E Suppl.):E55-E65. https://doi.org/10.3168/jds.S0022 -0302(04)70061-2.

Balikci, E., and M. Al. 2014. Some serum acute phase proteins and immunoglobulins concentrations in calves with rotavirus, coronavirus, E. coli F5 and Eimeria species. Iran J. Vet. Res. 15:397-401.

Beauchemin, K. A., D. Colombatto, D. P. Morgavi, and W. Z. Yang. 2003. Use of fibrolytic enzymes to improve feed utilization by ruminants. J. Anim. Sci. 81(E. Suppl. 2):E37-E47.

Beede, D. K. 2005. The most essential nutrient: Water. Pages 13-31 in Proc. 7th Western Dairy Management Conf., Reno, NV. Western Dairy Management Conference, Manhattan, KS.

Bouda, J., and P. Jagos. 1984. Biochemical and hematological reference values in calves and their significance for health control. Acta Vet. Brno 53:137-142. https://doi.org/10.2754/avb198453030137.

Castells, L., A. Bach, G. Araujo, C. Montoro, and M. Terré. 2012. Effect of different forage sources on performance and feeding behavior of Holstein calves. J. Dairy Sci. 95:286-293. https://doi.org/10 $.3168 /$ jds.2011-4405.

Chapman, C. E., P. S. Erickson, J. D. Quigley, T. M. Hill, H. G. Bateman II, F. X. Suarez-Mena, and R. L. Schlotterbeck. 2016 Effect of milk replacer program on calf performance and digestion of nutrients with age of the dairy calf. J. Dairy Sci. 99:2740-2747. https://doi.org/10.3168/jds.2015-10372.

Cremer, J., M. Arnoldini, and T. Hwa. 2017. Effect of water flow and chemical environment on microbiota growth and composition in the human colon. Proc. Natl. Acad. Sci. USA 114:6438-6443. https://doi.org/10.1073/pnas.1619598114.

Daneshvar, D., M. Khorvash, E. Ghasemi, A. H. Mahdavi, B. Moshiri, M. Mirzaei, A. Pezeshki, and M. H. Ghaffari. 2015. The effect of restricted milk feeding through conventional or step-down methods with or without forage provision in starter feed on performance of Holstein bull calves. J. Anim. Sci. 93:3979-3989. https:/ /doi.org/10.2527/jas.2014-8863.

Dennis, T. S., F. X. Suarez-Mena, T. M. Hill, J. D. Quigley, R. L. Schlotterbeck, and L. Hulbert. 2018. Effect of milk replacer feeding rate, age at weaning, and method of reducing milk replacer to weaning on digestion, performance, rumination, and activity in dairy calves to 4 months of age. J. Dairy Sci. 101:268-278. https:/ /doi.org/10.3168/jds.2017-13692.

Fraley, S. E., M. B. Hall, and T. D. Nennich. 2015. Effect of variable water intake as mediated by dietary potassium carbonate supplementation on rumen dynamics in lactating dairy cows. J. Dairy Sci. 98:3247-3256. https://doi.org/10.3168/jds.2014-8557.

Ganheim, C., S. Alenius, and W. K. Persson. 2007. Acute phase proteins as indicators of calf herd health. Vet. J. 173:645-651. https:/ /doi.org/10.1016/j.tvjl.2006.01.011. 
Gelsinger, S. L., A. J. Heinrichs, and C. M. Jones. 2016. A metaanalysis of the effects of preweaned calf nutrition and growth on first-lactation performance. J. Dairy Sci. 99:6206-6214. https:// doi.org/10.3168/jds.2015-10744.

Gottardo, F., S. Mattiello, G. Cozzi, E. Canali, E. Scanziani, L. Ravarotto, V. Ferrante, M. Verga, and I. Andrighe. 2002. The provision of drinking water to veal calves for welfare purposes. J. Anim. Sci. 80:2362-2372. https://doi.org/10.1093/ansci/80.9.2362.

Govil, K., D. S. Yadav, A. K. Patil, S. Nayak, R. P. S. Baghel, P. K. Yadav, C. D. Malapure, and D. Thakur. 2017. Feeding management for early rumen development in calves. J. Entomol. Zool. Stud. 5:1132-1139.

Gressley, T. F., M. B. Hall, and L. E. Armentano. 2011. Ruminant Nutrition Symposium: Productivity, digestion, and health responses to hindgut acidosis in ruminants. J. Anim. Sci. 89:1120-1130. https://doi.org/10.2527/jas.2010-3460.

Hall, M. B. 2009. Determination of starch, including maltooligosaccharides, in animal feeds: Comparison of methods and a method recommended for AOAC collaborative study. J. AOAC Int. 92:42-49.

Heinrichs, A. J., B. S. Heinrichs, C. M. Jones, P. S. Erickson, K. F Kalscheur, T. D. Nennich, B. J. Heins, and F. C. Cardosoll. 2017. Short communication: Verifying Holstein heifer heart girth to body weight prediction equations. J. Dairy Sci. 100:8451-8454. https:// doi.org/10.3168/jds.2016-12496.

Hill, T. M., H. G. Bateman II, J. M. Aldrich, and R. L. Schlotterbeck. 2010. Effect of milk replacer program on digestion of nutrients in dairy calves. J. Dairy Sci. 93:1105-1115. https://doi.org/10.3168/ jds.2009-2458.

Kang, H. J., I. K. Lee, M. Y. Piao, M. J. Gu, C. H. Yun, H. J. Kim, K. H. Kim, and M. Baik. 2016. Effects of ambient temperature on growth performance, blood metabolites, and immune cell populations in Korean cattle steers. Asian-Australas. J. Anim. Sci. 29:436-443. https://doi.org/10.5713/ajas.15.0937.

Kertz, A. F., T. M. Hill, J. D. Quigley, A. J. Heinrichs, J. G. Linn and J. K. Drackley. 2017. A 100-year review: calf nutrition and management. J. Dairy Sci. 100:10151-10172. https://doi.org/10 $.3168 /$ jds.2017-13062

Kertz, A. F., L. F. Reutzel, and J. H. Mahoney. 1984. Ad libitum water intake by neonatal calves and its relationship to calf starter intake, weight gain, feces score, and season. J. Dairy Sci. 67:29642969. https://doi.org/10.3168/jds.S0022-0302(84)81660-4.

Lane, M. A., R. L. Baldwin VI, and B. W. Jesse. 2000. Sheep rumen metabolic development in response to different dietary treatments. J. Anim. Sci. 78:1990-1996.

Montoro, C., E. K. Miller-Cushon, T. J. DeVries, and A. Bach. 2013 Effect of physical form of forage on performance, feeding behavior and digestibility of Holstein calves. J. Dairy Sci. 96:1117-1124. https://doi.org/10.3168/jds.2012-5731.

Murray, C. F., M. C. Windeyer, T. F. Duffield, D. B. Haley, D. L. Pearl, K. M. Waalderbos, and K. E. Leslie. 2014. Associations of serum haptoglobin in newborn dairy calves with health, growth, and mortality up to 4 months of age. J. Dairy Sci. 97:7844-7855. https://doi.org/10.3168/jds.2014-8465.

NRC. 2001. Nutrient Requirements of Dairy Cattle. 7th rev. ed. Natl. Acad. Press, Washington, DC.

Quigley, J. D., T. M. Hill, F. X. Suarez-Mena, T. S. Dennis, J. M. Aldrich, and R. L. Schlotterbeck. 2017. Modeling the effects of liquid intake and weaning on digestibility of nutrients in pre- and postweaned dairy calves. Pages 196-182 in Proc. 28th Annual Florida Ruminant Nutrition Symposium, Gainesville, FL. Florida Dairy Extension, University of Florida, Gainesville.

Quigley, J. D., T. A. Wolfe, and T. H. Elsasser. 2006. Effects of additional milk replacer feeding on calf health, growth, and selected blood metabolites in calves. J. Dairy Sci. 89:207-216. https://doi .org/10.3168/jds.S0022-0302(06)72085-9.

Ramin, A. G., S. Asri-Rezaei, K. Paya, Z. Eftekhari, M. Jelodary, H. Akbari, and S. Ramin. 2012. Evaluation of anemia in calves up to 4 months of age in Holstein dairy herds. Vet Scan 7:87-92.
Reece, W. O. 1980. Acid-base-balance and selected hematologic, electrolyte, and blood chemical-variables in calves: Milk-fed vs conventionally fed. Am. J. Vet. Res. 41:109-113.

Reid, J. T. G. H. Wellington, and H. O. Dunn. 1955. Some relationships among the major chemical components of the bovine body and their application to nutritional investigations. J. Dairy Sci. 38:1344-1359. https://doi.org/10.3168/jds.S0022-0302(55)95117 $-1$.

Rogers, J. A., C. L. Davis, and J. H. Clark. 1982. Alteration of rumen fermentation, milk fat synthesis, and nutrient utilization with mineral salts in dairy cows. J. Dairy Sci. 65:577-586. https://doi .org/10.3168/jds.S0022-0302(82)82235-2.

Rosenberger, K., J. H. C. Costa, H. W. Neave, M. A. G. von Keyserlingk, and D. M. Weary. 2017. The effect of milk allowance on behavior and weight gains in dairy calves. J. Dairy Sci. 100:504-512. https://doi.org/10.3168/jds.2016-11195.

Sasada, T., T. Hinoi, Y. Saito, T. Adachi, Y. Takakura, Y. Kawaguchi, Y. Sotomaru, K. Sentani, N. Oue, W. Yasui, and H. Ohdan. 2015. Chlorinated water modulates the development of colorectal tumors with chromosomal instability and gut microbiota in APC-deficient mice. PLoS One 10:e132435.

Sayers, R. G., A. Kennedy, L. Krump, G. P. Sayers, and E. Kennedy. 2016. An observational study using blood gas analysis to assess neonatal calf diarrhoea and subsequent recovery with a European Commission-compliant oral electrolyte solution. J. Dairy Sci. 99:4647-4655. https://doi.org/10.3168/jds.2015-10600.

Sekine, J., and Y. Hirose. 1968. Body water compartments of growing dairy calves. J. Fac. Agric. Hokkaido Univ. 56:57-66.

Terré, M., M. Devant, and A. Bach. 2007. Effect of level of milk replacer fed to Holstein calves on performance during the preweaning period and starter digestibility at weaning. Livest. Sci. 110:82-88. https://doi.org/10.1016/j.livsci.2006.10.001.

Thickett, W. S., T. D. Cuthbert, T. D. A. Brigstocke, M. A. Lindeman, and P. N. Wilson. 1981. The management of calves on an early-weaning system: The relationship of voluntary water intake to dry feed intake and live-weight gain to 5 weeks. Anim. Prod. 33:25-30. https://doi.org/10.1017/S0003356100025162.

Thomas, L. C., T. C. Wright, A. Formusiak, J. P. Cant, and V. R. Osborne. 2007. Use of flavored drinking water in calves and lactating dairy cattle. J. Dairy Sci. 90:3831-3837. https://doi.org/10.3168/ jds.2007-0085.

Trefz, F. M., P. D. Constable, and I. Lorenz. 2017. Effect of intravenous small-volume hypertonic sodium bicarbonate, sodium chloride, and glucose solutions in decreasing plasma potassium concentration in hyperkalemic neonatal calves with diarrhea. J. Vet. Intern. Med. 31:907-921. https://doi.org/10.1111/jvim.14709.

USDA. 2007. Dairy 2007, Part I: Reference of Dairy Cattle Health and Management Practices in the United States, 2007. USDA:APHIS: VS:CEAH, Fort Collins, CO.

USDA. 2016. Dairy 2014, Dairy Cattle Management Practices in the United States, 2014. USDA-APHIS:VS-CEAH-NAHMS, Fort Collins, CO.

Van De Stroet, D. L., J. A. Calderón Díaz, K. J. Stalder, A. J. Heinrichs, and C. D. Dechow. 2016. Association of calf growth traits with production characteristics in dairy cattle. J. Dairy Sci. 99:8347-8355. https://doi.org/10.3168/jds.2015-10738.

Van Soest, P. J., J. B. Robertson, and B. A. Lewis. 1991. Methods for dietary fiber, neutral detergent fiber, and nonstarch polysaccharides in relation to animal nutrition. J. Dairy Sci. 74:3583-3597. https://doi.org/10.3168/jds.S0022-0302(91)78551-2.

Wilson, L. L., C. L. Egan, and T. L. Terosky. 1997. Body measurements and body weights of special-fed Holstein veal calves. J. Dairy Sci. 80:3077-3082. https://doi.org/10.3168/jds.S0022 -0302(97)76277-5.

Winchester, C. F., and M. J. Morris. 1956. Water intake rates of cattle. J. Anim. Sci. 15:722-740. 